\title{
Efektivitas pembelajaran matematika melalui penerapan model pembelajaran kooperatif tipe snowball throwing
}

\section{Andi Mulawakkan Firdaus ${ }^{1}$}

\begin{abstract}
Abstrak: Penelitian ini merupakan penelitian Eksperimen semu yang bertujuan untuk mendeskripsikan hasil belajar siswa SMP Negeri 13 Makassar yang diajar dengan menggunakan Model Kooperatif Tipe Snowball Throwing dan Metode Ekspositori, serta untuk mengetahui apakah model pembelajaran kooperatif tipe Snowball Throwing efektif digunakan dalam pembelajaran matematika pada siswa kelas VIII SMP Negeri 13 Makassar. Luaran yang akan dihasilkan dari penelitian ini adalah penerapan alternatif pembelajaran yang tidak monoton sehingga dapat meningkatkan hasil belajar matematika siswa dan perangkat pembelajaran (silabus dan RPP) yang berorientasi pada pembelajaran koperatif tipe Snowball Throwing. Subjek penelitian dibagi dalam 2 kelompok, yakni kelompok eksperimen yang diajar dengan menggunakan pembelajaran kooperatif tipe Snowball Throwing dan kelompok kontrol yang diajar dengan menggunakan metode ekspositori. Setiap kelompok diajar dengan frekuensi pertemuan yang sama dengan materi yang sama. Hasil penelitian menunjukan bahwa penerapan model pembelajaran kooperatif tipe Snowball Throwing lebih efektif jika dibandingkan dengan penerapan metode ekspositori untuk pokok bahasan sistem persamaan linear dua variabel.
\end{abstract}

Kata kunci : Efektifitas Pembelajaran Matematika; Snowball Throwing; Metode Ekspositori.

\begin{abstract}
This experiment research aims to describe the learning outcomes of students at SMP Negeri 13 Makassar taught with snowball throwing (cooperative) and expository method, and to find out whether snowball throwing method is more effective in learning mathematics than expository method in grade 7 . The results of this research are implementing alternative learning method which is not monotonous to improve students' mathematics learning outcomes and producing learning tools that consist of syllabus and lesson plans based on snowball throwing method in cooperative learning. Research subjects are divided into two groups namely the experimental group taught with snowball throwing and the control group taught with expository method. Each group was taught with equal number of
\end{abstract}

${ }^{1}$ Universitas Muhammadiyah Makasar, Makasar, Indonesia, mulfiunesa@yahoo.com 
meetings and the same material. The result shows that the implementation of snowball throwing method is more effective than expository method for two variables linear equation system.

Keywords: Effectiveness of Learning Mathematics; Snowball Throwing; Expository Methods

\section{A. Pendahuluan}

Kemajuan ilmu pengetahuan dan teknologi telah mengalami perkembangan yang begitu pesat. Setiap negara berusaha mempersiapkan diri untuk dapat bersaing dengan negara lain. Salah satu usaha yang dilakukan adalah meningkatkan sumber daya manusia yang paling tepat dilaksanakan lewat jalur pendidikan. Pendidikan bertujuan untuk mengembangkan kualitas manusia. Sebagai suatu kegiatan yang sadar akan tujuan, maka dalam pelaksanaannya berada dalam suatu proses yang berkesinambungan dalam setiap jenis dan jenjang pendidikan. Semuanya berkaitan dalam suatu sistem pendidikan yang integral.

Anthony Robbins dalam Trianto (2011) mendefinisikan belajar sebagai proses menciptakan hubungan antara sesuatu (pengetahuan) yang sudah dipahami dan sesuatu (pengetahuan) yang baru. Dari definisi ini dimensi belajar memuat beberapa unsur, yaitu: (1) penciptaan hubungan, (2) sesuatu hal (pengetahuan) yang sudah dipahami, dan (3) sesuatu (pengetahuan) yang baru. Jadi dalam makna belajar, disini bukan berangkat dari sesuatu yang benar-benar belum diketahui (nol), tetapi merupakan keterkaitan dari dua pengetahuan yang sudah ada dengan pengetahuan baru.

Pelajaran matematika di sekolah merupakan pelajaran yang bersifat abstrak, sehingga diperlukan strategi pembelajaran yang tepat untuk mengajarkan matematika agar siswa lebih mudah memahami konsep yang terkandung dalam setiap materi yang dipelajari. Karena sampai saat ini masih banyak kesulitan yang dihadapi siswa dalam belajar matematika. Hal ini disebabkan karena banyaknya faktor-faktor tertentu, seperti anggapan bahwa pembelajaran matematika itu sulit. Sehingga hal tersebut akhirnya berpengaruh terhadap hasil belajar matematika. Semua ini bukan semata-mata hanya kesalahan siswa tetapi dapat juga karena penggunaan strategi pembelajaran yang kurang tepat. 
Berdasarkan observasi yang telah dilaksanakan peneliti di SMP Negeri 13 Makassar pada tanggal 6 Oktober 2015 bahwa pembelajaran yang biasa diterapkan guru dalam mengajarkan matematika adalah pembelajaran dengan metode ekspositori. Metode pembelajaran ekspositori adalah cara menyampaikan pembelajaran dari seorang guru kepada peserta didik di dalam kelas dengan cara berbicara di awal pelajaran, menerangkan materi, dan contoh soal (Nasution, 2007). Dalam mengajarkan matematika, guru secara aktif mengajar kemudian memberikan contoh soal dan penyelesaiannya, kemudian memberi soalsoal latihan, dan siswa disuruh mengerjakannya. Meskipun guru tidak terus menerus bicara, namun proses ini tetap menekankan penyampaian tekstual serta kurang mengembangkan motivasi dan kemampuan belajar siswa.

Metode ekspositori cenderung meminimalkan keterlibatan siswa sehingga guru nampak lebih aktif. Kebiasaan bersikap pasif dalam proses pembelajaran dapat mengakibatkan sebagian besar siswa takut dan malu bertanya pada guru mengenai materi yang kurang dipahami. Siswa cenderung merasa khawatir untuk mengungkapkan pendapat ataupun pertanyaannya. Suasana belajar di kelas menjadi sangat monoton dan kurang menarik. Pada metode ekspositori, proses pembelajaran berlangsung satu arah di mana guru memberikan informasi, gagasan, dan siswa menerima. Pendekatan itu lebih menekankan guru sebagai model sedangkan siswa dituntut mengikuti guru (Risal, 2009).

Masalah lain yang kerap kali muncul adalah banyak siswa yang malas belajar dan berlatih dan membiasakan memecahkan atau menyelesaikan soal-soal matematika jika tidak mendapat tugas dari gurunya. Untuk mengatasi permasalahan tersebut, maka solusi yang dipilih oleh peneliti adalah menggunakan model pembelajaran yang relevan. Salah satunya adalah model pembelajaran kooperatif tipe Snowball Throwing. Model ini merupakan model pembelajaran yang menggali potensi kepemimpinan siswa dalam kelompok dan keterampilan membuat dan menjawab pertanyaan yang dipadukan melalui suatu permainan imajinatif membentuk dan melempar bola salju.

Dengan model ini siswa kooperatif, dapat bertanya meskipun tidak pada guru secara langsung, mengemukakan pendapat, memiliki jiwa kepemimpinan serta membuat siswa tetap melakukan kegiatan belajar 
baik di sekolah maupun di lingkungan luar sekolah seperti rumah, sehingga siswa yang kurang paham terhadap materi yang disampaikan akan menjadi lebih mengerti karena adanya latihan yang dilakukan secara rutin. Dengan menggunakan model pembelajaran ini diharapkan siswa merasa senang dan antusias selama proses pembelajaran sehingga dapat menyelesaikan masalah. Dan juga diharapkan dapat menambah nuansa baru bagi pembelajaran matematika. Agar dalam pembelajarannya, keterampilan proses yang ada dapat berpengaruh positif terhadap hasil belajar.

Keefektifan program pembelajaran menurut Surya (2004) ditandai dengan ciri-ciri sebagai berikut:

a. Berhasil menghantarkan siswa mencapai tujuan-tujuan instruksional yang telah ditetapkan.

b. Memberikan pengalaman belajar yang atraktif, melibatkan siswa secara aktif sehingga menunjang pencapaian tujuan instruksional.

c. Memiliki sarana-sarana yang menunjang proses belajar mengajar.

Pembelajaran kooperatif (cooperative learning) merupakan strategi pembelajaran melalui kelompok kecil siswa yang saling bekerja sama dalam memaksimalkan kondisi belajar untuk mencapai tujuan belajar (Depdiknas dalam Komalasari, 2010). Bern dan Erickson (2001) mengemukakan bahwa cooperative learning (pembelajaran kooperatif) merupakan strategi pembelajaran yang mengorganisir pembelajaran dengan menggunakan kelompok belajar kecil dimana siswa bekerja bersama untuk mencapai tujuan pembelajaran. Suherman (2003) meyatakan bahwa pembelajaran adalah proses yang diatur sedemikian rupa menurut langkah tertentu agar pelaksanaannya mencapai hasil yang memuaskan.

Dari uraian di atas, penelitian ini bertujuan untuk mengetahui apakah model pembelajaran kooperatif tipe Snowball Throwing efektif digunakan dalam pembelajaran matematika pada siswa kelas VIII, juga untuk memperoleh deskripsi hasil belajar matematika siswa kelas VIII yang diajar dengan menggunakan pembelajaran kooperatif tipe Snowball Throwing dan metode ekspositori.

\section{B. Metode Penelitian}

Penelitian ini merupakan jenis penelitian eksperimen, yaitu metode penelitian yang digunakan untuk mencari pengaruh perlakuan tertentu 
terhadap yang lain dalam kondisi yang terkendalikan. Dalam penelitian ini melibatkan 2 kelompok, yaitu satu kelompok sebagai kelompok eksperimen (percobaan) dan satu kelompok sebagai kelompok kontrol (pembanding). Untuk kelompok eksperimen diajar dengan menggunakan model pembelajaran kooperatif tipe Snowball Throwing sedangkan pada kelompok kontrol diajar dengan menggunakan metode ekspositori. Adapun populasi dari penelitian ini adalah seluruh siswa kelas VIII SMP Negeri 13 Makassar pada semester genap tahun ajaran 2015/2016. Sampel dari penelitian ini terdiri dari dua kelas yang berjumlah 38 orang.

Jenis pengambilan sampel yang digunakan adalah random sampling, secara eklusi dengan sebuah undian yang dilakukan secara acak dari kelaskelas yang ada karena populasi pada penelitian ini homogen. Melalui teknik ini diperoleh kelas VIII.A sebagai kelas eksperimen dan kelas VIII.B sebagai kelas kontrol. Masing-masing kelas terdiri dari 19 orang siswa.

Setelah menetapkan subjek penelitian, maka pelaksanaan penelitian dilaksanakan sebagai berikut:

1. Pelaksanaan penelitian berlangsung selama 4 kali pertemuan

2. Menetapkan masing-masing siswa yang menjadi subjek penelitian ke dalam 2 kelompok, yakni kelompok eksperimen yang diajar dengan menggunakan pembelajaran kooperatif tipe Snowball Throwing dan kelompok kontrol yang diajar dengan menggunakan metode ekspositori.

3. Setiap kelompok diajar dengan frekuensi pertemuan dan materi yang sama

4. Pada akhir pembelajaran diberikan tes dengan bobot soal yang sama.

Instrumen penelitian yang akan digunakan adalah tes hasil belajar, Lembar Observasi Keterampilan Proses/ Aktivitas Siswa, Lembar Observasi Kemampuan Guru dalam Mengelola Pembelajaran, Angket Respon Siswa. Untuk menganalisis data yang diperoleh adalah dengan menggunakan analisis statistika deskriptif dan analisis statistika inferensial.

Pengumpulan data untuk hasil belajar siswa dilakukan dengan pemberian tes hasil belajar pada akhir perlakuan secara serentak kepada masing-masing responden pada kedua kelompok, yatu kelompok eksperimen dan kelompok kontrol. Data yang diperoleh merupakan data empirik yang kemudian akan dianalisis. 
Metode observasi menggunakan lembar pengamatan keterampilan proses peserta didik untuk mengamati kegiatan peserta didik dan lembar pengamatan untuk mengamati kemampuan guru dalam mengelola pembelajaran yang diharapkan muncul dalam pembelajaran matematika dengan model pembelajaran kooperatif tipe Snowball Throwing.

Teknik yang digunakan untuk memperoleh data respon siswa adalah dengan membagikan angket kepada siswa setelah berakhirnya pertemuan terakhir untuk diisi sesuai dengan petunjuk yang diberikan. Teknik analisis data yang digunakan untuk menganalisis data yang diperoleh adalah dengan menggunakan analisis statistika deskriptif dan analisis statistika inferensial.

Statistik deskriptif adalah statistik yang digunakan untuk menganalisis data dengan cara mendeskripsikan atau menggambarkan data yang telah terkumpul sebagaimana adanya, tanpa bermaksud membuat kesimpulan yang berlaku umum atau generalisasi, dalam Sugiyono (2010). Dalam penelitian ini, analisis statistik dekriptif digunakan untuk mendeskripsikan hasil belajar matematika siswa pada setiap kelompok yang telah dipilih.

Jenis data berupa hasil belajar selanjutnya dikategorikan secara kualitatif berdasarkan teknik standar pengkategorian dengan skala lima yang diterapkan oleh Departemen Pendidikan dan Kebudayaan, dalam Sanimbar (2011).

\section{Tabel 1. Teknik Kategori Standar Berdasarkan Ketetapan Depdiknas}

\begin{tabular}{|c|c|}
\hline Skor & Kategori \\
\hline $00-54$ & Sangat rendah \\
\hline $55-64$ & Rendah \\
\hline $65-79$ & Sedang \\
\hline $80-89$ & Tinggi \\
\hline $90-100$ & Sangat tinggi \\
\hline
\end{tabular}

Kriteria seorang siswa dikatakan tuntas belajar apabila memenuhi kriteria ketuntasan minimal yang ditentukan oleh sekolah yakni 65 .

Statistik inferensial adalah teknik statistik yang digunakan untuk menganalisis data sampel dan hasilnya diberlakukan untuk populasi. Teknik statistik ini dimaksudkan untuk menguji hipotesis penelitian. Sebelum menguji hipotesis penelitian, dilakukan uji normalitas dan uji homogenitas. 


\section{Uji Normalitas}

Uji normalitas merupakan langkah awal dalam menganalisis data secara spesifik. Uji normalitas digunakan untuk mengetahui data berdistribusi normal atau tidak. Pada penelitian ini digunakan uji One Sample Kolmogorov-Smirnov dengan menggunakan taraf signifikansi 5\% atau 0,05, dengan syarat:

Jika Pvalue $\geq 0,05$ maka distribusinya adalah normal Jika Pvalue $<0,05$ maka distribusinya adalah tidak normal.

\section{Uji Homogenitas}

Uji homogenitas dilakukan untuk menyelidiki variansi kedua sampel sama atau tidak. Uji yang digunakan adalah uji Levene's Test. Uji ini dilakukan sebagai prasyarat dalam analisis t-Test. Jika sampel tersebut memiliki variansi yang sama, maka keduanya dikatakan homogen. Pada uji Levene's Test digunakan taraf signifikansi $5 \%$ atau 0,05. Kriteria pengujian hipotesis adalah jika signifikansi lebih besar dari taraf signifikansi $\alpha=0,05$, maka secara statistik kedua varian sama atau data homogeny. Furqan (2008).

Adapun langkah-langkah dalam uji homogenitas adalah sebagai berikut:

a. Menentukan apakah kedua varian (kelompok eksperimen dan kelompok kontrol) adalah homogen atau tidak.

b. Kriteria pengujian (berdasarkan probabilitas/signifikansi)

Jika $P$ value $\geq 0,05$ maka kedua varian sama.

Jika $P$ value $<0,05$ maka kedua varian berbeda.

c. Membandingkan probabilitas

Nilai $P$ value $\geq 0,05$ maka kedua varian adalah sama

d. Menarik kesimpulan

Untuk menguji hipotesis nol, bahwa rata-rata dua kelompok tidak berbeda maka digunakan t-Test. Namun pada dasarnya keduanya akan menghasilkan kesimpulan yang sama, yaitu menerima atau menolak hipotesis nol. Pada penelitian ini dirumuskan hipotesis sebagai berikut:

$\mathrm{H}_{0}$ : Hasil belajar matematika siswa yang diajar menggunakan model pembelajaran kooperatif tipe Snowball Throwing lebih kecil atau sama dengan hasil belajar matematika siswa yang diajar menggunakan metode ekspositori. 
$\mathrm{H}_{1}$ : Hasil belajar matematika siswa yang diajar dengan menggunakan model pembelajaran kooperatif tipe Snowball Throwing lebih besar dibandingkan dengan hasil belajar matematika siswa yang diajar dengan metode ekspositori.

Atau:

$$
\begin{aligned}
& \mathrm{H}_{0}: \mu_{1} \leq \mu_{2} \\
& \mathrm{H}_{1}: \mu_{1}>\mu_{2}
\end{aligned}
$$

Dengan:

$\mu 1=$ Parameter hasil belajar matematika siswa yang diajar dengan menggunakan model pembelajaran kooperatif tipe Snowball Throwing.

$\mu 2=$ Parameter hasil belajar matematika siswa yang diajar dengan menggunakan metode ekspositori.

\section{Temuan dan Pembahasan}

Hasil statistik yang berkaitan dengan skor variabel yang diajar dengan menggunakan pembelajaran kooperatif tipe Snowball Throwing.

Tabel 2. Deskripsi Skor Hasil Belajar Matematika Siswa yang Diajar dengan Pembelajaran Kooperatif Tipe Snowball Throwing

\begin{tabular}{|l|c|}
\hline \multicolumn{1}{|c|}{ Statistik } & Nilai Statistik \\
\hline Ukuran Sampel & 19 \\
\hline Nilai terendah & 52 \\
\hline Nilai tertinggi & 92 \\
\hline Nilai rata-rata & 74,05 \\
\hline Standar deviasi & 10,31 \\
\hline Variansi & 106,39 \\
\hline Range & 40 \\
\hline
\end{tabular}

Pada Tabel 2 dapat dilihat bahwa skor rata-rata skor hasil belajar siswa kelas VIII SMP Negeri 13 Makassar yang diajar dengan menggunakan model pembelajaran kooperatif tipe Snowball Throwing adalah 74,05 dari skor ideal 100 yang mungkin dicapai oleh siswa. Skor yang dicapai oleh siswa tersebar dari skor terendah 52 sampai dengan skor tertinggi 92 dengan rentang skor 40 . Jika hasil belajar matematika siswa dikelompokkan ke dalam lima kategori maka diperoleh distribusi frekuensi dan persentase. 
Tabel 3. Distribusi dan Persentase Skor Hasil Belajar Matematika Siswa yang Diajar Snowball Throwing

\begin{tabular}{|c|c|c|c|c|}
\hline No & Skor & Kategori & Frekuensi & Persentase \\
\hline 1 & $00-54$ & Sangat rendah & 1 & $5,26 \%$ \\
\hline 2 & $55-64$ & Rendah & 2 & $10,52 \%$ \\
\hline 3 & $65-79$ & Sedang & 7 & $36,84 \%$ \\
\hline 4 & $80-89$ & Tinggi & 8 & $42,11 \%$ \\
\hline 5 & $90-100$ & Sangat tinggi & 1 & $5,26 \%$ \\
\hline \multicolumn{3}{|c|}{ Jumlah } & 19 & $100 \%$ \\
\hline
\end{tabular}

Pada Tabel 3 di atas menunjukkan bahwa dari 19 siswa kelas VIII SMP Negeri 13 Makassar, siswa yang memperoleh skor antara 00-54 sebanyak 1 siswa atau 5,26\%, 2 siswa atau 10,52\% memperoleh skor pada interval 55-64, 7 siswa atau 36,84\% memperoleh skor pada interval 65-79, 8 siswa atau 42,11\% memperoleh skor pada interval 80-89, dan 1 siswa atau 5,26\% siswa yang memperoleh skor pada interval 90-100. Berdasarkan Tabel 2 dan Tabel 3 dapat digambarkan bahwa dari 19 orang siswa kelas VIII SMP Negeri 13 Makassar yang dijadikan sampel penelitian untuk kelompok eksperimen, pada umumnya memiliki tingkat hasil belajar matematika dalam kategori tinggi dengan skor rata-rata 74,05 dari skor ideal 100.

Selanjutnya data skor hasil belajar siswa setelah diajar dengan model pembelajaran kooperatif tipe Snowball Throwing dianalisis berdasarkan kriteria ketuntasan.

Tabel 4. Deskripsi Ketuntasan Skor Hasil Belajar Siswa yang Diajar dengan Snowball Throwing

\begin{tabular}{|c|c|c|c|}
\hline Interval Skor & Kategori & Frekuensi & Persentase \\
\hline $0-64$ & Tidak Tuntas & 3 & $15,79 \%$ \\
\hline $65-100$ & Tuntas & 16 & $84,21 \%$ \\
\hline
\end{tabular}

Dari tabel 4 di atas menunjukkan bahwa 3 siswa atau 15,79\% siswa yang memiliki nilai yang tidak tuntas, sedangkan siswa yang memenuhi kriteria ketuntasan individu sebanyak 16 siswa atau 84,21\%.

Hasil statistik yang berkaitan dengan skor variabel yang diajar dengan metode ekspositori. 
Tabel 5. Deskripsi Skor Hasil Belajar Matematika Siswa yang Diajar dengan Metode Ekspositori

\begin{tabular}{|l|c|}
\hline \multicolumn{1}{|c|}{ Statistik } & Nilai Statistik \\
\hline Ukuran Sampel & 19 \\
\hline Nilai terendah & 45 \\
\hline Nilai tertinggi & 87 \\
\hline Nilai rata-rata & 66,21 \\
\hline Standar deviasi & 14,05 \\
\hline Variansi & 197,287 \\
\hline Range & 42 \\
\hline
\end{tabular}

Pada tabel 5 dapat dilihat bahwa skor rata-rata hasil belajar siswa kelas VIII SMP Negeri 13 Makassar yang diajar dengan metode ekspositori adalah 66,21 dari skor ideal 100 yang mungkin dicapai oleh siswa. Skor yang dicapai oleh siswa tersebar dari skor terendah 45 sampai dengan skor tertinggi 87 dengan rentang skor 42 . Jika hasil belajar matematika siswa dikelompokkan ke dalam lima kategori maka diperoleh distribusi frekuensi dan persentase sebagai berikut.

Tabel 6. Distribusi dan Persentase Skor Hasil Belajar Matematika Siswa yang Diajar dengan Metode Ekspositori

\begin{tabular}{|c|c|c|c|c|}
\hline No & Skor & Kategori & Frekuensi & Persentase \\
\hline 1 & $00-54$ & Sangat rendah & 4 & $21,05 \%$ \\
\hline 2 & $55-64$ & Rendah & 4 & $21,05 \%$ \\
\hline 3 & $65-79$ & Sedang & 5 & $26,32 \%$ \\
\hline 4 & $80-89$ & Tinggi & 6 & $31,58 \%$ \\
\hline 5 & $90-100$ & Sangat tinggi & 0 & $0 \%$ \\
\hline \multicolumn{3}{|c|}{ Jumlah } & 19 & $100 \%$ \\
\hline
\end{tabular}

Pada Tabel 6 di atas menunjukkan bahwa dari 19 siswa kelas VIII SMP Negeri 13 Makassar, siswa yang memperoleh skor antara 00-54 sebanyak 4 siswa atau 21,05\%, 4 siswa atau 21,05\% memperoleh skor pada interval 55-64, 5 siswa atau 26,32\% memperoleh skor pada interval 65-79, 6 siswa atau 31,58\% memperoleh skor pada interval 80-89, dan 0 siswa atau 0\% siswa yang memperoleh skor pada interval 90-100. Jika skor ratarata hasil belajar siswa sebesar 66,21 dikonversi ke dalam lima kategori di 
atas, maka skor rata-rata hasil belajar matematika siswa kelas VIII SMP Negeri 13 Makassar yang dijadikan sampel penelitian untuk kelas kontrol umumnya memiliki nilai dengan kategori tinggi. Selanjutnya data nilai hasil dianalisis berdasarkan kriteria ketuntasan sebagai berikut.

Tabel 7. Deskripsi Ketuntasan Skor Hasil Belajar Siswa yang Diajar dengan Metode Ekspositori

\begin{tabular}{|c|l|c|c|}
\hline Interval Skor & \multicolumn{1}{|c|}{ Kategori } & Frekuensi & Persentase \\
\hline $0-64$ & Tidak Tuntas & 8 & $42,11 \%$ \\
\hline $65-100$ & Tuntas & 11 & $57,89 \%$ \\
\hline
\end{tabular}

Dari pembahasan di atas, dapat ditarik kesimpulan bahwa penerapan model pembelajaran kooperatif tipe Snowball Throwing layak dan efektif digunakan dalam proses belajar mengajar, khususnya untuk materi sistem persamaan linear dua variabel (SPLDV) pada siswa kelas VIII SMP Negeri 13 Makassar.

Berdasarkan hasil penelitian, menunjukkan bahwa model pembelajaran kooperatif tipe Snowball Throwing dapat meningkatkan hasil belajar matematika siswa.

Hasil analisis dekskriptif menunjukkan bahwa hasil belajar matematika siswa kelas VIII SMP Negeri 13 Makassar yang diajar dengan menggunakan model pembelajaran kooperatif tipe Snowball Throwing pada pokok bahasan sistem persamaan linear dua variabel (SPLDV) berada pada kategori sangat rendah yaitu $5,2 \%$, kategori rendah $10,52 \%$, kategori sedang $36,84 \%$, kategori tinggi $42,11 \%$, kategori sangat tinggi $5,26 \%$, dan skor rata-rata sebesar 74,05 dengan standar deviasi 10,31.

Sementara itu hasil belajar matematika siswa kelas VIII SMP Negeri 13 Makassar yang diajar dengan metode ekspositori pada pokok bahasan sistem persamaan linear dua variabel (SPLDV) berada pada kategori sangat rendah yaitu $21,05 \%$, kategori rendah $21,05 \%$, kategori sedang $26,32 \%$, kategori tinggi $31,58 \%$, kategori sangat tinggi $0 \%$, dan skor ratarata sebesar 66,21 dengan standar deviasi 14,05.

Berdasarkan kriteria ketuntasan minimal (KKM) pada SMP Negeri 13 Makassar, yaitu siswa dikatakan tuntas belajarnya jika hasil belajarnya telah mencapai skor 65, maka pada kelas eksperimen siswa yang mencapai ketuntasan belajar adalah sebanyak 16 orang dari jumlah keseluruhan 19 orang dengan persentase $84,21 \%$. Adapun pada kelas 
kontrol siswa yang mencapai ketuntasan belajar adalah sebanyak 11 orang dari jumlah keseluruhan 19 orang dengan persentase $57,89 \%$. Dari beberapa pemaparan di atas, maka dapat dilihat bahwa pembelajaran dengan menggunakan model kooperatif tipe Snowball Throwing dapat meningkatkan ketuntasan belajar individu.

Hasil analisis inferensial menunjukkan bahwa terdapat perbedaan hasil belajar matematika siswa yang diajar dengan menggunakan model pembelajaran kooperatif tipe Snowball Throwing dengan siswa yang diajar dengan metode ekspositori, di mana hasil belajar siswa yang diajar dengan menggunakan model pembelajaran kooperatif tipe Snowball Throwing lebih tinggi dibandingkan dengan hasil belajar siswa yang diajar dengan metode ekspositori. Hal ini ditunjukkan oleh nilai thitung $>$ ttabel yaitu $1,964>1,68$. Perbedaan ini juga dapat dilihat dari rata-rata hasil belajar yang diperoleh oleh kedua kelompok dan ketuntasan belajar siswa. Sehingga dapat disimpulkan bahwa pembelajaran dengan menggunakan model kooperatif tipe Snowball Throwing untuk siswa kelas VIII SMP Negeri 13 Makassar lebih efektif daripada metode ekspositori untuk pokok bahasan sistem persamaan linear dua variabel (SPLDV).

Selain itu, pada kelas eksperimen siswa menjadi lebih tertarik mengikuti proses belajar mengajar yang kooperatif dan mampu membuat mereka lebih berani dan tidak was-was lagi dalam belajar. Mereka mampu berbaur, memotivasi teman yang lain dan tidak merasa dibeda-bedakan. Keaktifan pun nampak dengan antusias mereka dalam bertanya dan menjawab pertanyaan.

Pada siswa yang diajar dengan metode ekspositori, keterlibatan siswa dalam proses belajar mengajar kurang nampak. Peran guru sangat dominan karena harus menjelaskan materi dengan tuntas. Hal ini menyebabkan hanya beberapa siswa yang terlihat aktif dalam pembelajaran. Saat guru memberikan kesempatan untuk mengajukan pertanyaan, hanya beberapa siswa yang terlihat antusias. Sebagian besar siswa hanya duduk mendengar guru berceramah dan menyalin penjelasan yang diberikan oleh guru. Demikian pula saat guru memberikan latihan soal-soal, hanya beberapa siswa yang terlihat aktif mengerjakan soal-soal tersebut. Siswa memiliki kecenderungan menunggu jawaban dari guru. Oleh karena itu, pembelajaran kooperatif tipe Snowball Throwing sangat 
membantu siswa dalam meningkatkan hasil belajar matematikanya, khususnya siswa kelas VIII SMP Negeri 13 Makassar.

Dari segi keterlaksanaan kemampuan guru dalam mengelola pembelajaran dan respon siswa juga terlihat bahwa aspek dari pengelolaan pembelajaran yang dilaksanakan oleh guru di kelas pada saat mengajar menunjukkan kriteria yang sangat baik dan siswa memiliki respon positif terhadap model pembelajaran kooperatif tipe Snowball Throwing dibandingkan metode ekspositori. Sehingga dapat disimpulkan bahwa model pembelajaran kooperatif tipe Snowball Throwing pada siswa kelas VIII SMP Negeri 13 Makassar lebih efektif daripada pembelajaran ekpositori untuk pokok bahasan sistem persamaan linear dua variabel (SPLDV).

\section{Simpulan}

Berdasarkan hasil penelitian dan pembahasan maka dapat ditarik beberapa kesimpulan sebagai berikut:

1. Hasil belajar matematika siswa kelas VIII SMP Negeri 13 Makassar pada pokok bahasan sistem persamaan linear dua variabel (SPLDV) yang diajar melalui model pembelajaran kooperatif tipe Snowball Throwing memiliki skor rata-rata sebesar 74,05 dengan standar deviasi 10,31 dari skor ideal yang mungkin dicapai yaitu 100.

2. Hasil belajar matematika siswa kelas VIII SMP Negeri 13 Makassar pada pokok bahasan sistem persamaan linear dua variabel (SPLDV) yang diajar melalui metode ekspositori memiliki skor ratarata sebesar 66,21 dengan standar deviasi 14,05 dari skor ideal yang mungkin dicapai yaitu 100.

3. Ditinjau dari ketuntasan belajar siswa, aktivitas siswa, kemampuan guru dalam mengelola pembelajaran dan respon positif siswa maka penerapan model pembelajaran kooperatif tipe Snowball Throwing pada siswa kelas VIII SMP Negeri 13 Makassar lebih efektif jika dibandingkan dengan penerapan metode ekspositori untuk pokok bahasan sistem persamaan linear dua variabel (SPLDV). 


\section{Ucapan Terima Kasih}

Penulis mengucapkan terima kasih kepada kedua orang tua yang selalu mendoakan dan memberikan motivasi, kakanda Nasrun, S.Pd., M.Pd yang tidak henti-hentinya membimbing penulis dalam melaksanakan penelitian sampai pada penyusunan artikel, serta kepala sekolah SMP Negeri 13 Makassar yang telah memberikan izin untuk melaksanakan penelitian.

\section{Daftar Pustaka}

Berns, R.G. \& Erickson, P.M. (2001). Contextual Teaching and Learning: Preparing students for the new economy. Diakses di http://eric.ed.gov/?id=ED452376

Furqan. (2008). Statistik terapan untuk penelitian. Bandung, Indonesia: Alfabeta.

Komalasari, K. (2010). Pembelajaran kontekstual konsep dan aplikasinya. Bandung, Indonesia: PT Refika Aditama.

Nasution, W. N. (2007). Efektivitas pembelajaran kooperatif dan ekspositori terhadap hasil belajar sains ditinjau dari cara berpikir (Artikel jurnal). Diakses di http://www.litagama.org/jurnal/Edisi5/StrategiPemb.htm.

Risal, N.A. (2009). Efektivitas pembelajaran matematika berbasis pendekatan realistik (Skripsi). FMIPA UNM, Makassar.

Sanimbar. (2011). Penerapan model pembelajaran kooperatif tipe two staytwo stray pada siswa kelas VIII ${ }_{B}$ SMP Negeri 2 Sajoanging (Skripsi). FKIP UNISMUH, Makassar.

Sugiyono. (2010). Metode penelitian kuantitatif, kualitatif, dan $R \& D$. Bandung, Indonesia: Alfabeta.

Suherman, E. (2003). Strategi pembelajaran matematika kontemporer. Bandung, Indonesia: Universitas Pendidikan Indonesia.

Suprijono, A. (2011). Cooperative learning teori \& aplikasi PAIKEM. Yogyakarta, Indonesia: Pustaka Pelajar.

Surya, M. (2004). Psikologi pembelajaran \& pengajaran. Bandung, Indonesia: Pustaka Bani Quraisy.

Trianto. (2011). Mendesain model pembelajaran inovatif-progresif. Jakarta, Indonesia: Kencana. 